\title{
European pension reforms and property investments
}

Received: 5th January, 2004

\section{Richard McLemore}

is a Vice President in the Investment Research Department of Prudential Real Estate Investors (PREI). His primary responsibility is international research. He received a BSc in finance from the University of Tennessee and an MSc in finance from Louisiana State University.

\section{David Skinner}

joined PRICOA Property plc in 2003 to head European research. Previously Head of Investment Research at DTZ, he holds an MSc in economics from the University of Warwick and a PhD in economics from the University of Salford.

\section{Max Beekmann}

joined PREI Europe/TMW in the spring of 2001. His responsibilities include market analysis of European institutional real estate markets. He studied spatial planning in Dortmund and Liverpool.

\begin{abstract}
Important changes are coming quickly to Europe's retirement savings industry. Funds are under pressure to consider investment in a portfolio context, and are giving more serious consideration to alternative investments. As new regulations and standards of best practice emerge, funds will increasingly consider broadening their exposure to alternative investments, particularly property, which compares favourably with stocks and bonds on a total potential return and return-to-risk-ratio basis. This paper shows that, based on some fairly conservative assumptions, property should perform well when compared with other asset classes.
\end{abstract}

Keywords: pension reform; property; asset allocation; alternative investments; correlation; diversification

Richard McLemore

PREI

8 Campus Drive,

Parsippany,

NY 07054, USA.

Tel +1973683 1674; e-mail: prei.research@ prudential.com

\section{Introduction}

Ageing populations and increased longevity are putting pressure on retirement savings systems in most developed countries worldwide. Although Europe has many pension structures and age profiles, the retirement systems in some of its largest economies will face several challenges in the coming decades.

On the liability side, a wave of retirements will cause rapid growth in the number of pensioners and an increase in overall pension liabilities. On the asset side, the industry faces one of the toughest investment climates in recent history. Like elsewhere, economic growth in the region has slowed. Capital market conditions have deteriorated, in part, due to the tech market collapse, war, and general weakness in world demand. Stock market yields are low, and although pricing multiples have fallen, they remain high compared to historical averages. Bond yields have also declined to near historic lows, providing few choices for income from traditional debt vehicles and little opportunity for appreciation. Given current contribution rates and the likely potential performance of stock and bond investments, pension performance seems unlikely to meet projected funding needs. 


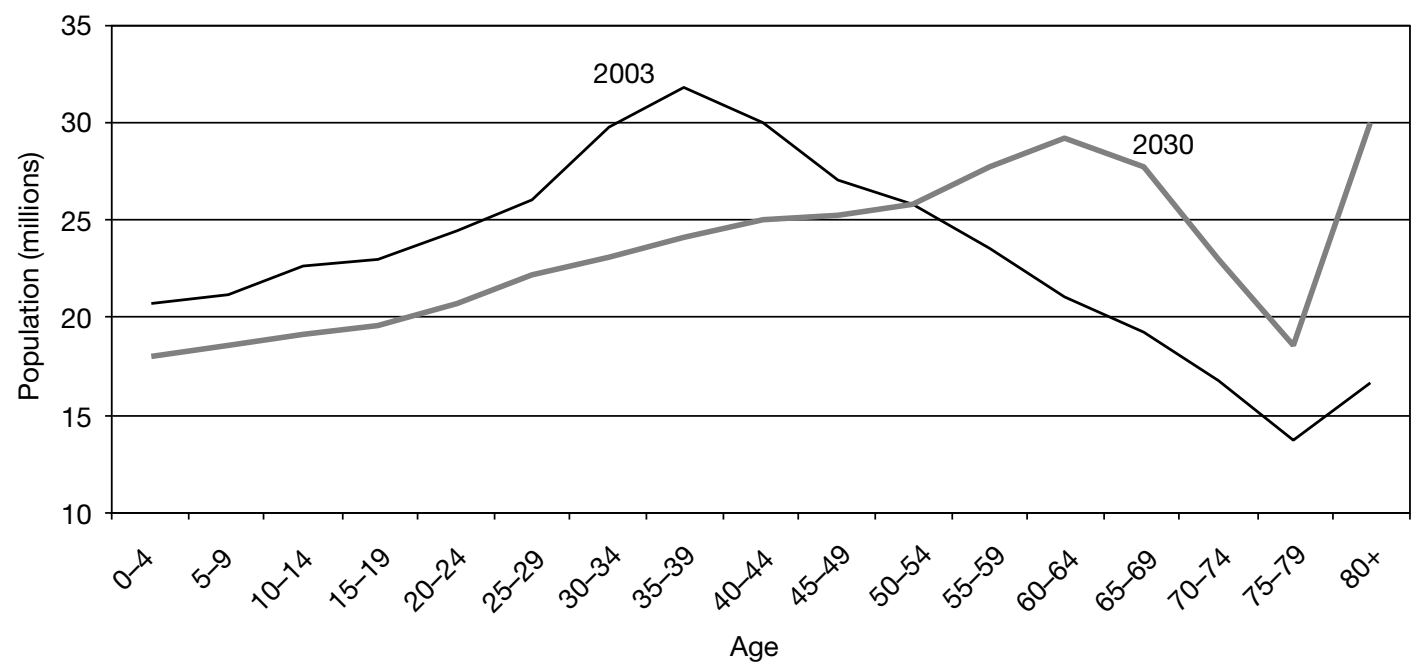

Source: International Data Base, US Bureau of the Census

Figure 1: Demographic projections for Western Europe

This predicament has not gone unnoticed, and governments are taking important steps to mitigate the problem. Increasing productivity, retirement ages, working hours, labour participation rates, immigration, taxes or contributions are all under consideration. Many local authorities are also making regulatory changes to help ensure pension asset preservation. Regulatory bodies have begun to take a greater interest in asset allocation, and fund managers are increasingly encouraged (either by market conditions or actual regulations) to consider their investments in a portfolio context.

In this context, the benefits of property investment are well known. It provides strong diversification benefits for pension assets, as it has a low correlation with both stocks and bonds, and a consistently high yield, which is beneficial for liability matching. Less well known is that, given the current global investment environment, in many countries property compares favourably to equities and bonds on a total potential return basis. This paper shows that, based on some fairly conservative assumptions, property should perform well when compared with other asset classes.

\section{Europe's greying society}

The ageing of the European population is particularly problematic in the more developed Western markets, where pension assets are largest. A dramatic change will occur in Western Europe's age distribution during the next 30 years (see Figure 1). The median age will increase from 39.5 in 2003 to 46.7 in 2030. At first glance, this may not seem striking, but the devil is in the details. Western Europe will add almost 33 million people age 65 or older by 2030 , increasing the current elderly population by more than 50 per cent.

The population wave consisting of those currently aged 30 to 49 will soon be nearing retirement age. This wave, along with increasing longevity and decreasing birth rates, will cause a rapid rise in the elderly population. The macroeconomic impact of this ageing is best illustrated by examining the ratio of 
elderly dependents to the working-age population. Currently in Western Europe, the ratio is about 3.6 working age (ages 20 to 64) people for every elderly person (defined here as age 65+, although the retirement age is below 65 in several countries). By 2030, the ratio will have declined to 2.2 workers for every elderly dependent. This contrasts sharply with areas such as Latin America, where the current ratio is more than nine workers per elderly dependent and will remain over three for the next 50 years. Clearly, many of the pay-as-you-go (PAYG) systems in Europe (discussed in more detail later), which largely rely on current member contributions to fund current retiree benefits, will face challenging times if reforms are not enacted.

\section{A pension primer and reform overview}

The ageing population has forced a serious reassessment of current pension schemes across Europe. In many cases, today's pension systems are in danger. The reason lies in the structure of most of these systems, which fall into three categories: (a) social security schemes, the state-sponsored PAYG systems, which are the root of most of the potential problems; (b) occupational schemes, also called 'second pillar' pensions, which are corporate-sponsored savings systems where employer and employee contribute to the fund and retirement benefits are paid out from the fund; and (c) individual schemes, usually products offered through life-assurance companies.

Occupational pension scheme development is in its infancy in many European markets. This type of programme only covers about one-quarter of the economically active population in the European Union (EU) and is concentrated in a few countries.
Individual private savings schemes are difficult to quantify but play a very important role in several countries. In France, for example, the private savings industry is estimated to be worth $€ 1$.6trn, making it one of Europe's largest.

Most pension schemes in Europe are PAYG systems, which means that contributions from current workers fund the benefits of retired employees. The plans are not substantially funded, meaning they are not required to account fully for the present value of future probable benefit liabilities. Therein lies the problem: an ageing population, with increasing demands for retirement benefits, matched with a relatively stagnant working-age population to pay for them. This, compounded with comparatively generous benefit packages, has resulted in continuity risk for the PAYG pension funds.

Figure 2 illustrates the problem in several countries. Current gross social security retirement income as a percentage of average income is shown next to the occupational pension coverage in each country as a percentage of the total working population. Not surprisingly, the countries that provide the most generous social security benefits have the lowest participation in, and availability of, occupational pension plans. As the populations age and begin to strain the economies of the countries that must pay generous benefits, few corporate or individual retirement plans exist to share the burden. Given the ample benefits from the social security schemes, few pensioners have seen the need for supplementary retirement income.

Although Figure 2 highlights countries where the ageing impacts may be greatest (Italy, Greece, Spain and Portugal, for example), it hides some important flaws in other countries' 


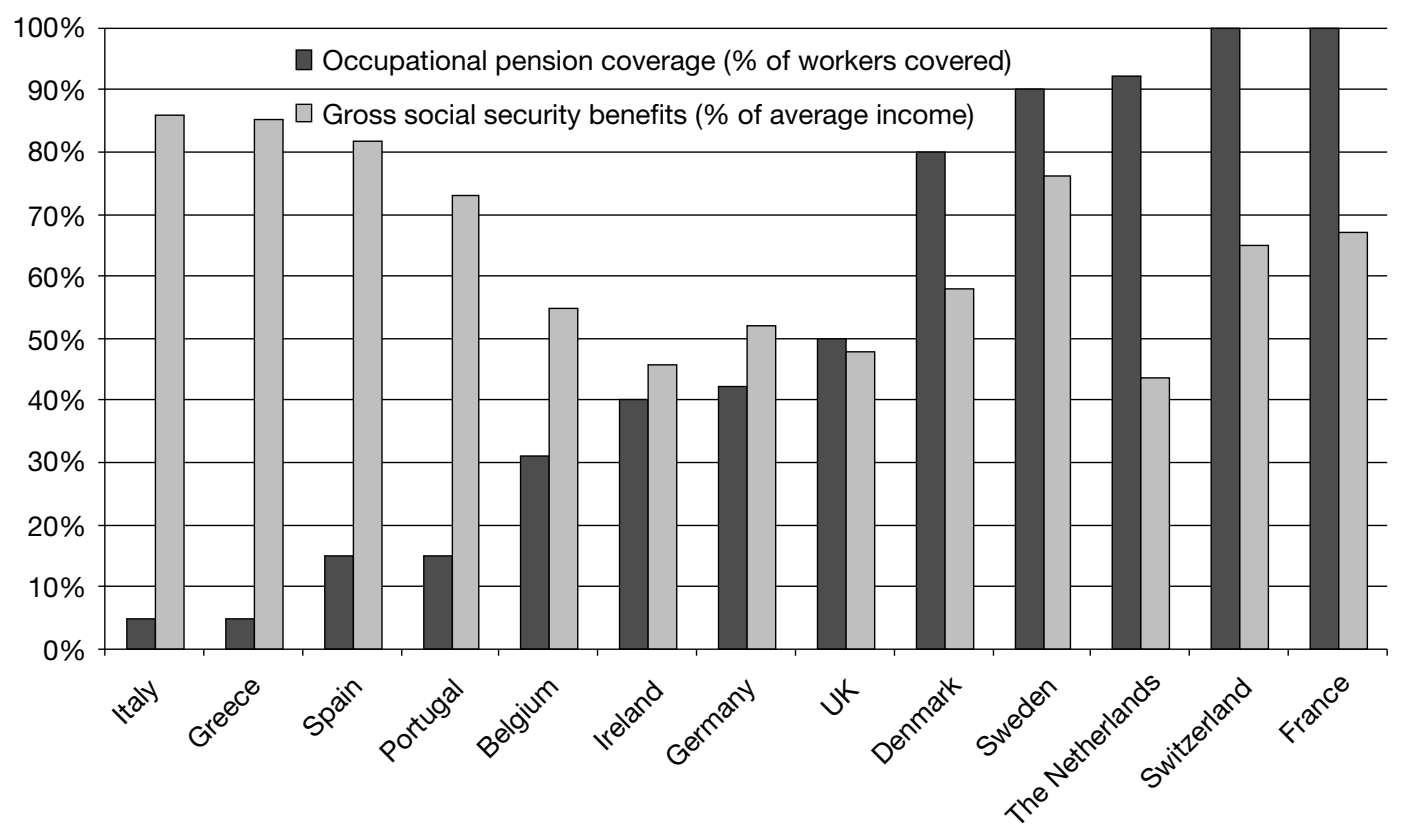

Sources: Commerzbank Securities; William M. Mercer; OECD

Figure 2: Current benefits and occupational scheme coverage

systems. Germany has one of the EU's largest projected pension deficits, with a current PAYG liability of $\$ 4$.6trn over the next 40 years - roughly double the country's estimated 2002 nominal gross domestic product (GDP). ${ }^{1}$ France offers all employees the option of occupational pensions, but such assets represent only about 5 per cent of GDP.

The pension problem is not being ignored. Administrations are enacting reforms to head off disaster. Although these changes may prevent some of the economic strain, none is politically popular. Governments have or will cut benefits, increase retirement ages, and/or raise taxes or contributions. These reforms, however, do not specifically address the problem but rather 'patch' it temporarily and so defer tackling the true issue. The restoration of retirement security for Europeans can only happen through the expansion of the second and third pension fund types. The burden of retirement savings must be transferred to, or at least shared with, individuals and corporations. This will mean government promotion and regulation of occupational and individual pension programmes.

Most countries' reform agendas are following similar paths, with the EU pushing for regional consistency. In the works is a common EU pension market, which would be governed by one set of standards. It would allow the transport of pensions across borders, which would provide greater labour mobility and could permit multinational firms to offer a single EU pension plan. The current differing asset allocations and restrictions among pension systems mean that some countries will have to modify their present regulations. For example, the UK, the Netherlands and Belgium allow pension managers a high degree of flexibility in asset allocation, holding the manager to the 'prudent person rule'. Germany and France, on the other hand, have much more restrictive guidelines for what is an appropriate pension fund 


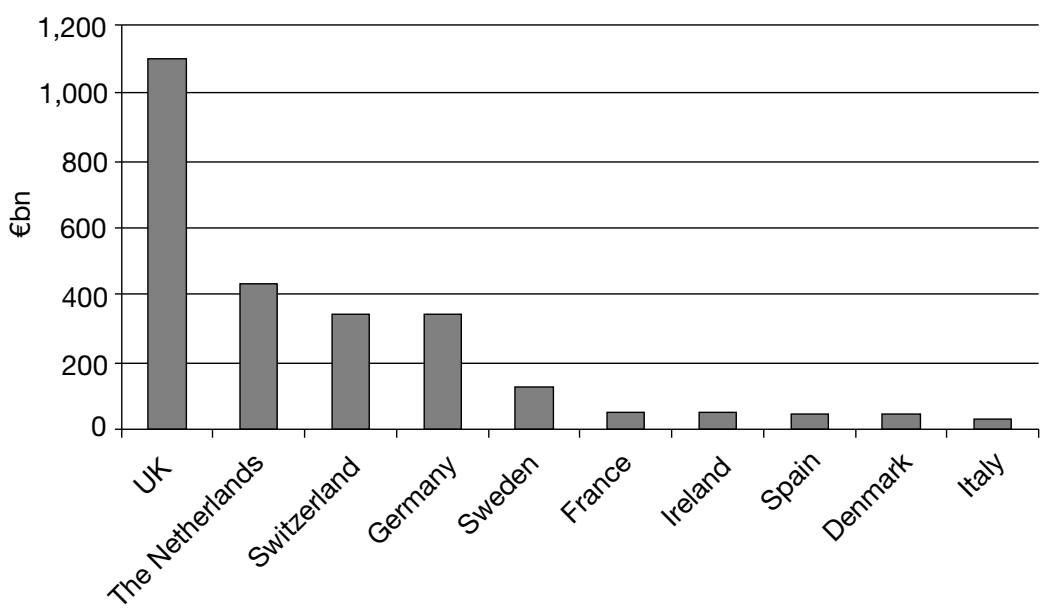

Source: European Federation for Retirement Provision

Figure 3: Second pillar pension fund assets - 2001 (Countries with €30bn+)

investment and place specific restrictions on certain types of investments, such as the percentage of total assets that can be held in foreign securities.

The details of the reforms will largely determine their impact on the investment markets, but any regional standardisation of plans will involve the movement of capital. For example, the funding standards for EU pensions are still in question. The level and composition of required funding will greatly determine the magnitude of the capital flows and the types of assets in greatest demand. A high funding requirement tends to lessen the attractiveness of more volatile investments, such as equities. Numerous other regulatory factors concerning pension funds, such as tax treatment, have yet to be determined. These decisions could materially impact pension investment preference.

Regardless of the details, a relatively large and immediate inflow of investment capital is likely to occur. Some analysts suggest that corporate pension schemes could grow from the current $€ 3$.5trn to more than $€ 17$ trn as early as 2020 . $^{2}$
Credit Suisse First Boston argues that net institutional investment inflows could reach $€ 500$ bn annually over the next ten years, with perhaps less investment in the early years. ${ }^{3}$ With these inflows, European capital markets will experience dramatic changes. The financial services infrastructure will probably see rapid expansion and development as savings capital enters the existing systems and new systems form. The additional demand for investment vehicles could be substantial.

Attractive investment options for this influx of capital are currently limited. Consider the local traditional investment options in four of the largest second pillar pension markets, as ranked by total pension fund assets in second pillar schemes. The four largest include the UK, the Netherlands, Germany and Switzerland (see Figure 3). As the following discussion will illustrate, traditional investment options (stocks and bonds) in most of the developed or developing pension markets provide only limited yield and appreciation potential, especially in light of the potential downside risks. Pension funds that have 


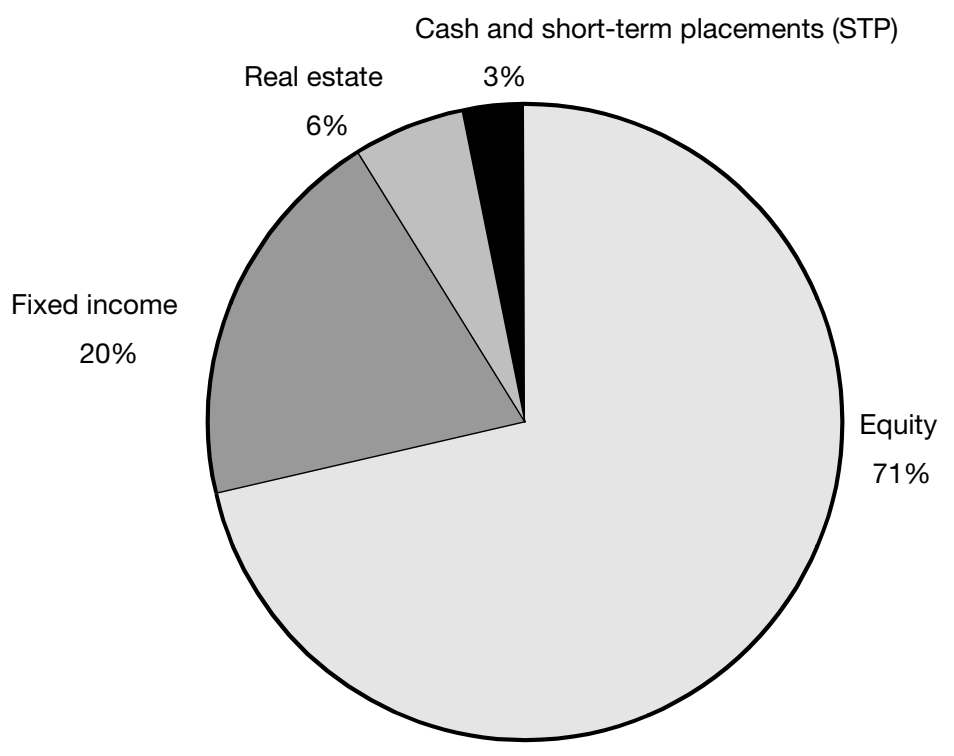

Source: European Federation for Retirement Provision

Figure 4: UK second pillar asset allocation - 2001

traditionally concentrated their investments in stocks and bonds will increasingly be forced to consider alternative investments to meet their performance requirements.

\section{The UK}

The UK has, by far, the largest base of second pillar pension assets in Europe. It also has the most developed and efficient pension system. Even in the UK, which is probably one of the best-positioned countries to withstand population ageing, reforms will be necessary. The pressure for reform recently intensified with the release of the Sandler Review, ${ }^{4}$ which proposed savings reforms, and the subsequent Pickering Report, ${ }^{5}$ which focused more specifically on necessary changes in the pension industry. Both suggested broad and difficult transformations in retirement savings policies and programmes.

The stress created by an ageing population and floundering investment markets has threatened the long-term stability of the system and has prompted legislation to assist in shoring up the plans. This legislation was spurred by the rapid deterioration in funding status, which largely resulted from excessive allocations to equities. Currently, UK pension funds hold a relatively high (almost three-quarters) allocation in equities (see Figure 4). Equities and fixed income together comprise more than 90 per cent of UK second pillar pension investments. As in most developed markets, UK stocks have fallen precipitously since reaching a valuation peak near the end of 1999.

The required adoption of the FRS 17 accounting standard, which mandates that companies record the market value of pension fund assets and liabilities on their balance sheets, has made the severity of the underfunding problem all too clear in financial statements. According to the Confederation of British Industry, the FTSE 100 companies face an aggregate pension deficit of close to $\mathcal{E}_{100 \mathrm{bn} \text {, and }}$ UK private-sector nonfinancial corporations face a deficit of roughly 
£160bn. ${ }^{6}$ Some estimates put the shortfall as high as $£^{280 b n}{ }^{7}$

Although the solution to the underfunding problem will be multifaceted, one of the most important aspects will be a reconsideration of asset allocation. The Myners Report identifies shortfalls in the current system and suggests a 'Code of Best Practice' for UK pension funds. ${ }^{8}$ The Report recommends that more attention be focused on strategic asset allocation and that funds consider the full range of investment opportunities, including some of the asset classes usually ignored, such as derivatives, private equity and property.

A recent paper prepared for the Pensions Institute examines the likely consequences of the Myners Report. ${ }^{9}$ It argues that going forward, asset classes will be selected based on their match with liabilities in terms of correlation and volatility rather than simply expected return. In this asset allocation framework, property plays an important role because it has historically exhibited a relatively low correlation to other asset classes and a relatively high correlation to fund liabilities. Another academic study found that, when considering asset/liability matching issues for mature UK pension funds, optimal asset allocation included about 10 per cent to property in all but the funds with the highest risk appetite. ${ }^{10}$

Funds that do not make immediate and meaningful changes in allocation face a particularly challenging investment environment. Even ignoring the benefits of diversification and liability matching, the prospects for investment performance in property are relatively attractive compared with stocks and bonds.

While the outlook for the UK Stock Market is not bleak, it is not likely that returns will reach the lofty levels of the late 1990s. Between 1993 and 2002, the average annual total return of the FTSE
100 was about 6.6 per cent. Returns ranged from 28.5 per cent in 1997 to -21.5 per cent in 2002. Although total return has seen a wide variation, the yield on the index has remained relatively constant, ranging from about 2 per cent to 5 per cent, with an average of about 3.5 per cent. Relatively volatile price/earnings $(\mathrm{P} / \mathrm{E})$ ratios have caused wide swings in index value. The $\mathrm{P} / \mathrm{E}$ ratio reflects a culmination of both the market's changing estimates of earnings and its pricing of risk surrounding these earnings and future earnings growth. From September 1993 through to July 2003 , the index's $\mathrm{P} / \mathrm{E}$ ratio ranged from 13.1 to $25.7 .^{11}$ The yield on the index is now about 3.8 per cent, with a $\mathrm{P} / \mathrm{E}$ ratio of 20.1 per cent. Given this historical perspective, it is relatively easy to prognosticate the potential performance of the market.

If, over the next ten years, yields on stocks remain close to their current level, and if annual earnings growth averages 5 per cent (significantly higher than current economic growth forecasts), and if the $\mathrm{P} / \mathrm{E}$ ratio trends down to its historical average of 18.6, the total annual return to stocks during this period will be about 8 per cent. The base-case scenario is higher than actual average performance over the last ten years. But, the return may still be shy of the assumptions that many funds currently make regarding the long-term expected return from stocks. For the optimists, the authors present a scenario where annual earnings growth accelerates to 7 per cent and $\mathrm{P} / \mathrm{E}$ ratios rise to their historic high of 25.7 , in which case total return averages 13.5 per cent. On the pessimistic side, earnings growth is only 2 per cent (roughly equal to forecasted inflation), and the $\mathrm{P} / \mathrm{E}$ ratio falls to its historic low, in which case the annual total return falls to 1.6 per cent. Based on these historical parameters, UK stock 


\begin{tabular}{lccc}
\hline & Base & Optimistic & Pessimistic \\
\hline Stocks & $8.0 \%$ & $13.5 \%$ & $1.6 \%$ \\
Bonds & $1.5 \%$ & $4.8 \%$ & $-3.8 \%$ \\
Property & $9.0 \%$ & $14.6 \%$ & $4.1 \%$ \\
\hline
\end{tabular}

Sources: Bonds - Merrill Lynch UK Gilts Index as of 19th August, 2003, modified duration of 7.8 years; Stocks - FTSE 100 Index as of 5th August, 2003; Property - IPD UK Property Index as of 2002

Figure 5: Potential ten-year annual returns of UK investments

market investing could return from 1.6 per cent to 13.5 per cent annually over the next ten years.

The outlook for UK Gilts is decidedly worse. Their current yield is about 4.1 per cent. ${ }^{12}$ Since 1986 , the yield on Gilts has ranged from about 4 per cent to 13 per cent. The average yield over this period was around 7.8 per cent. If yields stay the same, investors in Gilts will earn 4.1 per cent. If, over the next ten years, yields drop by 110 basis points to 3 per cent (100 basis points below their historic low), the annual return to investors would be about 4.8 per cent. A seemingly more realistic scenario would be for interest rates to rise. If, as a base case, we assume that rates rise to their historic average of 7.8 per cent, the annual return for Gilts will be 1.5 per cent. On the downside, if rates rise to their historic high of 13 per cent, the total annual return would be about -3.8 per cent. Based on historical parameters, Gilts could therefore be expected to return between -3.8 per cent and 4.8 per cent annually over the next ten years.

In the UK, core, ungeared investment in property currently yields about 6.5 per cent. Since 1971, initial property yields have ranged from 4 per cent in 1973 to 9.2 per cent in 1992. Over the next four years, inflation in the UK is forecasted to average around 2 per cent annually, which we use as an estimate for long-term inflation and property investment income growth. As Figure 5 illustrates, if property yields fall only slightly to their historic average over the next ten years, and income growth averages 2 per cent, the effect would be a total return for property investments of 9 per cent annually. In the optimistic case, income growth averages 3 per cent, while yields fall to their historic low, which pushes total annual return up to 14.6 per cent. Even in the pessimistic case, which assumes property yields rise to their historic high and income growth is only 1 per cent, total return is still 4.1 per cent. Thus, property investment in the UK, based on its historical parameters, can be expected to return between 4.1 per cent and 14.6 per cent annually over the next ten years.

In addition to its favourable diversification and liability matching attributes, property compares quite favourably to the traditional asset classes based solely on return potential. UK funds with an excessive allocation to equities should consider diversifying their asset allocation using alternative investments, particularly property, in the current investment environment.

\section{The Netherlands}

The Netherlands also has a relatively developed pension market, with challenges similar to those in the UK. Dutch second pillar pensions have a more diversified asset allocation than those in the UK, with only 49 per cent in equities (see Figure 6). Like the UK, 


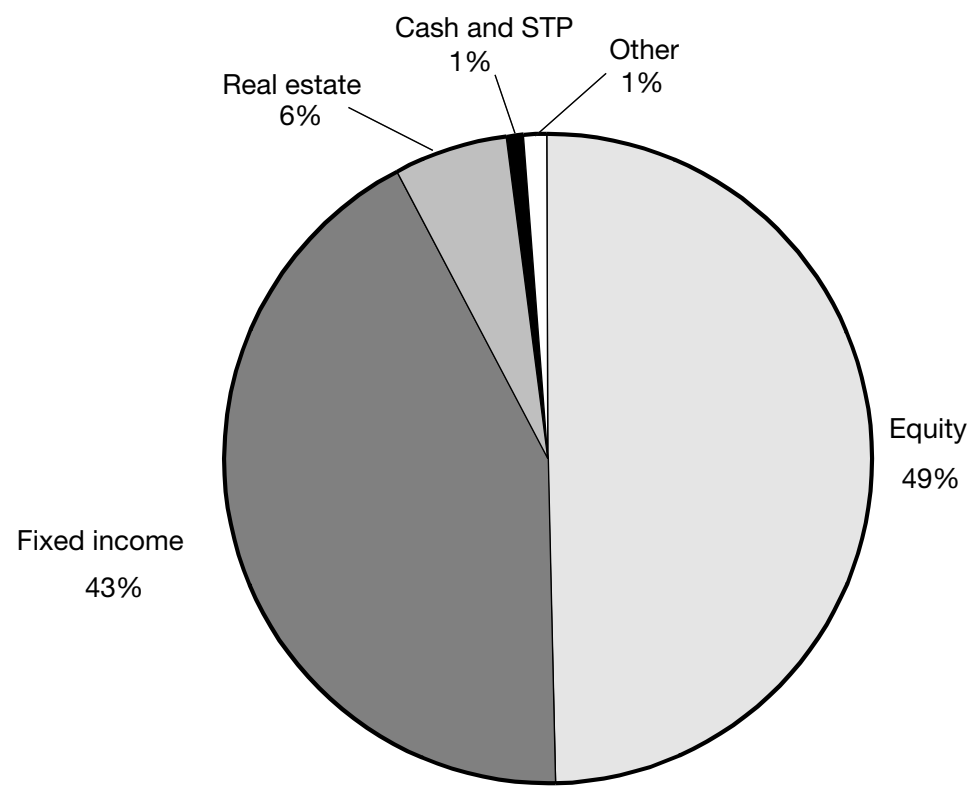

Source: European Federation for Retirement Provision

Figure 6: Netherlands second pillar asset allocation - 2001

however, equities and fixed income combined comprise more than 90 per cent of the funds' investments, despite property's proven portfolio benefits for Dutch pensions. Van Erp finds that investing 10 per cent to 15 per cent in private property is justified due to the diversification potential and decreasing shortfall probability. ${ }^{13}$ In the current market environment, this high degree of allocation to stocks and bonds may present a risk to achieving fund return targets.

As in the UK, the outlook for the stock market in the Netherlands is not unpromising, but returns are unlikely to achieve the heights seen in the late 1990s. From 1995 through 2002, the average annual total return of the Amsterdam Exchanges Index (AEX) was roughly 9.5 per cent. The Dutch equities market exhibited slightly more volatility than that of the UK. Returns to the AEX ranged from -36.3 per cent in 2002 to 43.7 per cent in 1997 . The yield on the index has averaged 3.4 per cent since September 1996, with the current yield around 3.5 per cent. The AEX's $\mathrm{P} / \mathrm{E}$ ratio, which has been relatively volatile, has caused wide swings in the index value. From March 1997 through to June 2003, the $\mathrm{P} / \mathrm{E}$ ratio of the index ranged from 9.4 to $26.2 .{ }^{14}$ The yield on the index is now about 3.5 per cent, with a $\mathrm{P} / \mathrm{E}$ ratio of $14 .{ }^{15}$

If yields on Dutch stocks stay near their current level, earnings growth averages 5 per cent (significantly higher than near-term projections for growth in real GDP), and the $\mathrm{P} / \mathrm{E}$ ratio moves up to its historical average, the total annual return to stocks in the next ten years should be around 11.2 per cent. An optimistic scenario would have annual earnings growth accelerating to 7 per cent and $\mathrm{P} / \mathrm{E}$ ratios rising to their historic high, in which case total return averages 17.5 per cent. In a pessimistic scenario, earnings growth is only 2 per cent (still slightly higher than forecasted 


\begin{tabular}{lrrr}
\hline & Base & Optimistic & Pessimistic \\
\hline Stocks & $11.2 \%$ & $17.5 \%$ & $1.6 \%$ \\
Bonds & $1.6 \%$ & $3.6 \%$ & $-0.1 \%$ \\
Property & $7.9 \%$ & $11.5 \%$ & $4.0 \%$ \\
\hline
\end{tabular}

Source: Bonds - Merrill Lynch Dutch Governments Bond Index as of 30th June, 2003, modified duration of 5.4 years; Stocks - AEX Index as of 5th August, 2003; Property - IPD Netherlands Property Index as of 2002

Figure 7: Potential ten-year annual returns of Netherlands investment

inflation) and the $\mathrm{P} / \mathrm{E}$ ratio declines to its historic low. In this case annual total return falls to 1.6 per cent. Using these guidelines, stock market investing in the Netherlands can expect to return between 1.6 per cent and 17.5 per cent annually over the next ten years, a relatively wide range of outcomes reflective of the market's historical volatility.

The outlook for Dutch bonds, whose yield is about 3.1 per cent, is sombre. ${ }^{16}$ Since 1986, the average yield has ranged from a high of 9.2 per cent to the current low of about 3.1 per cent, with an average of roughly 6.1 per cent. Given that yields are now at an historic low, substantial value gains from bonds seem improbable. The risk is that yields will rise. If yields remain the same, investors will earn 3.1 per cent. If, in an optimistic case for bond investors over the next ten years, bond yields fall by 110 basis points to 2 per cent, bonds would return about 3.6 per cent annually. In our base case, we assume rates increase to their historic average of 6.1 per cent. In this case, the annual return would be 1.6 per cent. If rates rise to their historic high, however, total annual return would decline to about -0.1 per cent.

Based on data from IPD, core, ungeared investment in Dutch property now yields about 6.4 per cent. The historic data for property investment in the Netherlands is limited, but in general yields have remained between 6 per cent and 9 per cent. Inflation in the Netherlands is projected to average around 1.5 per cent annually over the next four years. ${ }^{17}$ This is used as an estimate for long-term inflation and property investment income growth. If property yields remain constant over the next ten years and income growth averages 1.5 per cent, then total return for property investments would be 7.9 per cent annually. The optimistic case shows income growth averaging 2.5 per cent, while yields fall by 140 basis points, which raises total annual return to 11.5 per cent. Even in the pessimistic case, which assumes property yields rise 260 basis points to 9 per cent, and income growth averages only 1 per cent, annual total return still averages 4 per cent.

While the Dutch stock market's potential seems more attractive than that of the UK, a very wide range of outcomes is possible, reflecting the higher historic volatility of the market. Property return potential, while lower on the base and optimistic cases, has a much tighter range of potential outcomes. Also, the outlook for property investing compares quite well with that of bonds. In fact, the pessimistic return for property is higher than the optimistic return for bonds.

\section{Germany and Switzerland}

Pension funds in Germany differ from those in the UK and the Netherlands in 
that they hold a relatively high fixed-income allocation and a limited allocation to equities. ${ }^{18}$ The current yield on German bonds is around 3.1 per cent, near a historic low. ${ }^{19}$ About the best that local bond investors can realistically expect is stability in yields, with the risk that rates rise. If, during the next ten years, German bond yields decline by 110 basis points to 2 per cent, the annual return to investors would only be about 3.6 per cent. On the other hand, if rates rise to their historic average of 5.8 per cent, the annual return for German bonds would be 1.7 per cent. On the downside, if rates rise to their historic high of 9.2 per cent, the total annual return would be about -0.3 per cent. The stock market outlook is better but not outstanding. A substantial portion of the upside has already been realised in the first half of 2003. The German Stock Index (DAX) faces low current yields of around 2.3 per cent and limited upside on pricing, with a current $\mathrm{P} / \mathrm{E}$ ratio of 20.5 versus a historic average of $22.7 .^{20}$

Property again compares very favourably with stocks and bonds. Based on data from IPD, core, ungeared investment in German property currently yields roughly 6.2 per cent, double the yield available on bonds. The historic data for property investment in Germany are limited to 1996 to 2002, but in general yields have remained between 6 per cent and 7 per cent. Inflation in Germany is forecast to average about 1 per cent annually over the next four years, which can be used as an estimate of property investment income growth. If property yields remain constant over the next ten years, and income growth averages 1 per cent, total return for property investments would be 7.2 per cent annually. In the optimistic case, income growth averages 2 per cent, while yields fall by 120 basis points, which lifts total annual return to 10.4 per cent. Even in the pessimistic case, which assumes property yields rise 200 basis points (far beyond their recent historical high) to 8.2 per cent, with no income growth, total return is still 3.4 per cent, about the same as the optimistic case for bonds.

In Switzerland, pension fund performance is also in danger. Data from the Association of Swiss Pension Funds suggests that about 43 per cent of Swiss occupational pension schemes are underfunded. ${ }^{21}$ Asset allocation of Swiss second pillar funds is similar to that of the Dutch funds, with almost 90 per cent of investments in equity and fixed income. ${ }^{22}$ This asset allocation does not bode well for fund performance. The SMI Index currently yields around 1.7 per cent and has a $\mathrm{P} / \mathrm{E}$ ratio of 18.5 . The $\mathrm{P} / \mathrm{E}$ ratio has ranged from 11.5 to 28 , averaging about 19 over the last nine years. If earnings grow by 5 per cent annually and the $\mathrm{P} / \mathrm{E}$ ratio trends to its historic average, the total return for Swiss stocks would be approximately 7 per cent. On the upside, assuming higher earnings growth and the $\mathrm{P} / \mathrm{E}$ rising to its historic high, stock returns will be roughly 13 per cent. On the downside, with earnings growth of only 3 per cent and the $\mathrm{P} / \mathrm{E}$ ratio dropping to its historic low of 11.5 , stock returns are basically flat.

Swiss bonds do not hold much promise. Their current yield is around 2.1 per cent. ${ }^{23}$ Since 1986 , the average yield on Swiss bonds has ranged from its current low of 2 per cent to 7.3 per cent, averaging 4.3 per cent. Even if yields drop by 110 basis points to 1 per cent, the annual return to investors would only be about 2.8 per cent. If rates rise to their historic average of 4.3 per cent, the annual return for Swiss bonds will be 0.6 per cent. If they rise to their historic high of 7.3 per cent, the 
total annual return would be about -2 per cent.

Prime office property yields in Zurich are now about 4.8 per cent, among the lowest in Europe, but still substantially higher than the average yield available on Swiss bonds. ${ }^{24}$ Since 1990 , yields on Swiss property have remained between 4 per cent and 6 per cent. Inflation in Switzerland will probably average around 1.1 per cent annually over the next four years, which we can use as a base-case estimate for long-term inflation and property investment income growth. ${ }^{17}$ If property yields rise slightly to 5 per cent over the next ten years, which is close to their historic average since 1990, and income growth averages 1.1 per cent, then the total return for property investments would be 5.3 per cent annually, outperforming bonds in even their most optimistic case. In the optimistic case for property, income growth averages 2.5 per cent while yields fall to 4 per cent (close to their historic low), which pushes total annual return up to 9 per cent. Even in the pessimistic case, which assumes property yields rise to their recent historic high (6 per cent) with only 0.5 per cent annual income growth, total return is still 2.9 per cent.

Based on assumptions using historic pricing data and projected economic performance, property's base-case return (5.3 per cent) over the next ten years is lower than the base case for stocks ( 7 per cent), but the range is roughly half that of stocks. Stocks could return between 0 per cent and 13 per cent, while property returns are more likely to be between 2.9 per cent and 9 per cent. On a return-per-unit-of-risk basis, property compares very favourably to stocks. Compared with the Swiss bond market, property easily outperforms. Swiss bonds have a low current yield of less than half that of property investments. Based on historic averages, very little upside potential exists. Swiss property returns dominate bond returns by at least four percentage points in the base, optimistic and pessimistic scenarios.

\section{Regional recap}

Across four primary European economies, reasonable optimistic, pessimistic and base-case return scenarios were compiled using historical parameters for the primary return determinants of the domestic stock, bond and property markets. In general, these base-case scenarios involved assuming 'reversion to the mean' for investment pricing, along with some conservative assumptions about inflation and economic growth. In stocks, the base-case scenarios typically involved yields remaining at the current level, earnings growth roughly equal to forecasted real GDP growth and P/E ratios trending to their historical average. In bonds, the base case assumed yields trend to their historical average. In property, income growth is assumed to equal forecasted inflation, and yields are assumed to trend toward an estimated historical average.

As Table 1 illustrates, in these base-case scenarios, property provides a very competitive potential average annual total return over the next ten years in all four countries. On average, property's base-case ten-year average annual total return is only 130 basis points lower than that of stocks and exceeds the average annual total return for bonds by about 600 basis points.

While the base-case scenarios provide a good benchmark for near-term potential performance based on history, they may not accurately incorporate some important trends that may impact performance in the longer term. For example, this exercise may beg the question of how the forecasted population changes between 2010 and 2050 will impact the outlook 
Table 1: Potential ten-year annual returns

\begin{tabular}{lrrr}
\hline & Base & Optimistic & Pessimistic \\
\hline UK & & & \\
Stocks & $8.0 \%$ & $13.5 \%$ & $1.6 \%$ \\
Bonds & $1.5 \%$ & $4.8 \%$ & $-3.8 \%$ \\
Property & $9.0 \%$ & $14.6 \%$ & $4.1 \%$ \\
The Netherlands & & & \\
Stocks & $11.2 \%$ & $17.5 \%$ & $1.6 \%$ \\
Bonds & $1.6 \%$ & $3.6 \%$ & $-0.1 \%$ \\
Property & $7.9 \%$ & $11.5 \%$ & $4.0 \%$ \\
Germany & & & \\
Stocks & & $14.6 \%$ & $0.6 \%$ \\
Bonds & $8.4 \%$ & $3.6 \%$ & $-0.3 \%$ \\
Property & $1.7 \%$ & $10.4 \%$ & $3.4 \%$ \\
& $7.2 \%$ & & \\
Switzerland & & $13.2 \%$ & $-0.1 \%$ \\
Stocks & $7.0 \%$ & $2.8 \%$ & $-2.0 \%$ \\
Bonds & $0.6 \%$ & $9.0 \%$ & $2.9 \%$ \\
Property & $5.3 \%$ & & \\
\hline
\end{tabular}

Sources: Merrill Lynch Government Bond Indices; FTSE 100 Index; AEX Index; DAX Index; SMI Index; IPD Property Indices; Bloomberg; CB Richard Ellis; Prudential Real Estate Investors

for the property sector relative to other asset classes, stocks in particular. In the longer term, an ageing, and eventually declining, population seems likely to put downward pressure on returns across virtually all asset classes in Europe, as it has in Japan. The pessimistic return scenario is useful as a tool for comparing potential downside scenarios over the intermediate term across the primary asset classes.

Historically, property returns have been less volatile than those of stocks; therefore the range between potential optimistic and pessimistic return outcomes for property is narrower than that of stocks. While property has an appreciation component associated with changing potential for income growth, the volatility of this appreciation is not as high as that of stocks. Local stock market returns are largely driven by changes in $\mathrm{P} / \mathrm{E}$ ratios, which in turn are influenced by corporate earnings expectations and the risk surrounding these earnings. Corporate earnings are much more volatile and harder to predict than income from property.
While it may not always hold true, generally, in areas with declining populations, it seems reasonable to expect decreasing economic activity and corporate earnings, or at least declines in earnings growth, which should translate into more conservative stock market valuations. The same scenario is likely in the property market, but to a lesser degree. The demand for property is inherently tied to population, employment and income trends. With property, however, more of the projected total return is driven by yield. Property's relatively high yield causes its outperformance in the pessimistic case and makes its returns potentially less affected by population trends. Even if potential income growth from property were affected to the same degree as earnings growth for stocks, the aggregate effect on property returns would not be as dramatic due to the insulation provided by the higher yields. Also, the ageing population profile and expansion of pension liabilities may translate into greater relative demand for income 
investment vehicles, which could provide support to property values.

\section{Summary}

Undoubtedly, important changes are coming quickly to Europe's retirement savings industry. Across the region, retirement systems face structural reforms. Many countries' second pillar pension systems must be created or expanded and promoted. In countries with developed second pillar systems, reforms are necessary to ensure the long-term viability of the systems. In general, all European pension schemes will be forced to re-examine their benefit payouts and consider increasing fund contributions. The final component of reform that has not drawn much attention is portfolio management, but this is changing.

Standards that promote, or even mandate, strategic asset allocation are becoming more common. Funds are increasingly under pressure to consider investment in a portfolio context, and thus are giving more serious consideration to alternative investments. The existing defined benefit pension funds in Europe have historically maintained a relatively small allocation to property. With few exceptions, most countries' funds hold 10 per cent or less. As new regulations and standards of best practice emerge, funds will increasingly consider broadening their exposure to alternative investments, particularly property.

Property presents the new and expanded pension schemes with a unique asset class. It provides a relatively high and stable income yield, which should be attractive to pension funds for liability-matching purposes. Property also compares favourably with stocks and bonds on a total potential return and return-to-risk ratio basis. As noted, in the UK, the Netherlands, Germany and
Switzerland, yields and potential total returns for property investing are higher than those of bonds. Also, as government bond issuance declines through the transfer of retirement liabilities to the private sector, government debt securities may become more difficult to obtain and possibly even less liquid. As the population ages and its preference for investment income and stability increases, the demand for income-producing securities in individual savings schemes will increase. This may put upward pressure on bond prices and keep yields low, fostering the need for alternative, higher-yielding pension investments for liability matching purposes.

While the outlook for the various national stock markets in Europe is not bleak, achieving returns comparable to those of the late 1990s is not likely. As local economies have struggled, the potential for earnings growth has fallen. Also, $\mathrm{P} / \mathrm{E}$ ratios are near historic averages, so the possibility of price increases related to multiple expansion is muted. The likely payouts for investing in equities are not as high as the additional risk associated with the range of possible outcomes, depending on which direction earnings and multiples head. In the current environment, property compares favourably with stocks on the basis of return per unit of risk.

Finally, property has a low correlation with the traditional asset classes. Adding or increasing property allocations can raise the overall efficiency of a pension investment portfolio. In addition, the continued integration of countries in the EU will tend to increase the cross-country correlation of the stock and bond markets. This will reduce the diversification benefit that funds have enjoyed while pursuing international investments in the past. Property performance is, and will continue to be, locally driven, and will become an even 
more important source for international diversification of institutional investment portfolios.

In summary, property has the right characteristics to meet the goals and objectives of long-term, income-conscious investors. Thus, property investment should increasingly become a vital component of the reformed retirement savings schemes in Europe.

\section{References}

1 Commerzbank Securities (2002) 'Pension reforms in Europe - Europe's Enron: Implications for equities, bonds and alternative investments', 5th April.

2 Ibid

3 Credit Suisse First Boston (2001) 'Euro Area Special - Re-centering the debate on pensions', 5th July.

4 Sandler, R. (2002) 'Sandler Review: Medium and Long-Term Retail Savings in the UK', July.

5 Pickering, A. (2002) 'A Simpler Way to Better Pensions', July.

6 Confederation of British Industry (2003) 'Focus on Investment - The impact of pension deficits', Economic Brief, July.

7 Life Insurance International (2003) 'Launching a lifeboat?', 24th June.

8 Myners, P. (2001) 'Institutional Investment in the United Kingdom: A Review', March.

9 Blake, D. (2003) 'UK Pension Fund Management After Myners: The Hunt for Correlation Begins', Pensions Institute, University of London, Birbeck College.

10 Booth, P. M. (2002) 'Real estate investment in an asset/liability modeling context', Journal of Real Estate Portfolio Management, Vol. 8, No. 3, p. 193.

11 Based on month-end index-adjusted $\mathrm{P} / \mathrm{E}$ ratios as reported by Bloomberg.
12 Merrill Lynch UK Gilts Index as of 30th June, 2003. Macaulay duration has remained between five and eight since 1986 but has been rising. We assume duration of the index stays constant at its current 7.8 over the forecast period.

13 Van Erp, A. P. (1998) 'Onroerend goed in de beleggingsportefeuille van een pensioenfonds', Thesis for the University of Tilburg, carried out at ING Investment Management, referenced in 'The role of real estate in a balanced portfolio', ING Real Estate Investment Management, November 2001.

14 Based on month-end index-adjusted $\mathrm{P} / \mathrm{E}$ ratios as reported by Bloomberg.

15 Estimates based on 5th August, 2003, values as reported by Bloomberg.

16 Merrill Lynch Dutch Governments Bond Index as of 30th June, 2003. In general, Macaulay duration has remained between four and six since 1986 . To simplify, we assume duration of the index stays constant at its current 5.4 over the forecast period.

17 Country Indicators, Economist Intelligence Unit, September 2003.

18 Most recent data available from European Federation for Retirement Provision was 1998.

19 Merrill Lynch German Federal Governments Bond Index as of 30th June, 2003. In general, Macaulay duration has remained between four and six since 1986. To simplify, we assume duration of the index stays constant at its current 5.6 over the forecast period.

20 Yield on the DAX as of 5th August, 2003, as reported by Bloomberg.

21 'ASIP says 40 per cent of Swiss Schemes Underfunded', IPE.com, 3rd June, 2003.

22 European Federation for Retirement Provision, 2001.

23 Merrill Lynch Swiss Government Bond Index, 30th June, 2003. In general, Macaulay duration has remained between four and 7.3 since 1986 . We assume duration of the index stays constant at its current 7.3 over the forecast period.

24 Ellis, C. B. R. (2004) 'Zurich Office Market', Office Market Index Brief, Q4. 